\title{
The Example of the Quartzite from the "Upper Quartzite Formation" from Trás-os-Montes and Alto Douro (Northern Portugal); its Characterization to Use as Natural Stone
}

\author{
Sílvia Aires ${ }^{1, a}$, Fernando Noronha ${ }^{1, b}$, Cristina Carvalho ${ }^{2, \mathrm{c}}$, \\ António Casal Moura ${ }^{2, \mathrm{~d}}$ and João Farinha Ramos ${ }^{2, \mathrm{e}}$ \\ ${ }^{1}$ Centro de Geologia da Universidade do Porto - FCUP, DGAOT, Rua do Campo Alegre 687, \\ 4169-007 Porto, Portugal \\ ${ }^{2}$ LNEG - Rua da Amieira, Apartado 1089, 4466-901 S. Mamede de Infesta, Portugal \\ asilviayres@hotmail.com, bfmnoronh@fc.up.pt, ccristina.carvalho@lneg.pt, \\ dcasal.moura@Ineg.pt, ${ }^{\mathrm{e}}$ farinha.ramos@Ineg.pt
}

Keywords: Alto-Douro, Natural Stone, Portugal, Quartz Phyllite, Quartzite, Trás-Os-Montes.

\begin{abstract}
Metaquartzite from Serra da Garraia and Zebras were studied. These rocks belong to the "Upper Quartzite Formation" of the "Parautochthonous Complex". They are light grey and present, sometimes, a brownish patina. The quarries range from 2 to $10 \mathrm{~m}$ high and 25 to $40 \mathrm{~m}$ long. This study consists on the petrographic, chemical and physical-mechanical characterization of these rocks, aiming the determination of their potential as natural stone. The petrographic studies revealed that the rocks are formed by quartz and white mica and accessory opaque minerals (titanomagnetite, magnetite, and hematite) and zircon. The petrographic studies and $\mathrm{SiO}_{2}$ and $\mathrm{Al}_{2} \mathrm{O}_{3}$ values revealed a different evolution for Garraia and Zebras in terms of textural maturity and mineralogical differentiation. The studies allowed the distinction between quartzites and quartz phyllites. The physical-mechanical analyses attest that all the studied rocks can be used as natural stones.
\end{abstract}

\section{Introduction}

The purpose of this work was to characterize the quartzite rocks from Garraia Mountain and Zebras locality in terms of ornamental stones and to give a contribution for the increase of the population's interest in the use of this geological resource.

Several methods were applied to study those rocks, such as geological survey, mineralogy and petrography (optical microscopy, scanning electron microscopy, X-ray diffraction, and separation of heavy minerals), geochemistry and physical and mechanical tests (determination of water absorption at atmospheric pressure, determination of apparent density and of open porosity, determination of compressive strength, determination of flexural strength under concentrated load, determination of the abrasion resistance by wide wheel abrasion test, and determination of resistance to ageing by thermal shock).

\section{Geology}

The studied outcrops are located in Trás-os-Montes and Alto Douro (TMAD), in NE of Portugal. The exploitations of Garraia ( $\mathrm{Ga} 1$ and Ga2 samples) are located in Garraia Mountain, Palheiros parish, Murça municipality in Vila Real district. The exploitations of Zebras (Zb1 and Zb2 samples) also belong to the Vila Real district, and are located in Zebras area, Vales parish, near the Santa Comba and Garraia Mountains, in the Valpaços municipality.

Trás-os-Montes and Alto Douro (TMAD) is located in the NW sector of the Iberian Massif (IM). The studied sites are situated in the "Galiza Trás-os-Montes Zone" (GTMZ), in the "Parautochthonous Complex" (Fig. 1). They belong to the "Upper Quartzite Formation" (SPQ) Upper Silurian in age $[1,2,3]$. 


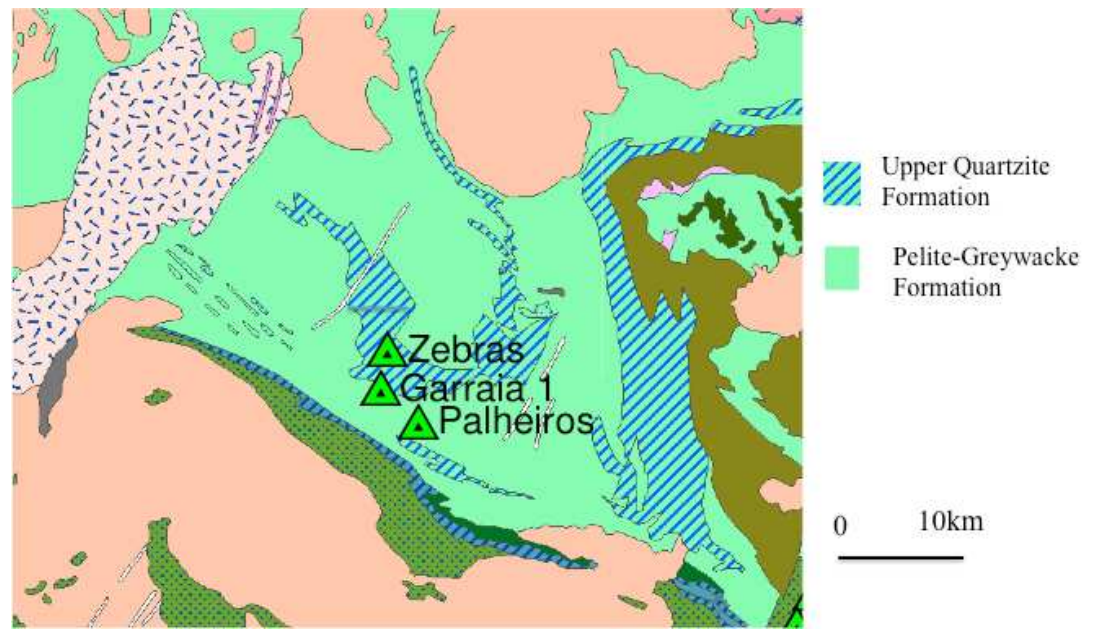

Fig. 1 - Localization of studied sites (From [2], adapted).

\section{Quarries Characterization}

Garraia 1 is a quarry $5 \mathrm{~m}$ high and $40 \mathrm{~m}$ long. The quartzite is laminated, exhibiting a greyish colour with a brownish patina. The rock exhibits a sub-horizontal slate cleavage $\mathrm{N} 90^{\circ} \mathrm{E}$ to $\mathrm{N} 110^{\circ} \mathrm{E}$ (Fig. 2 ). There are several joint systems (Fig. 3).

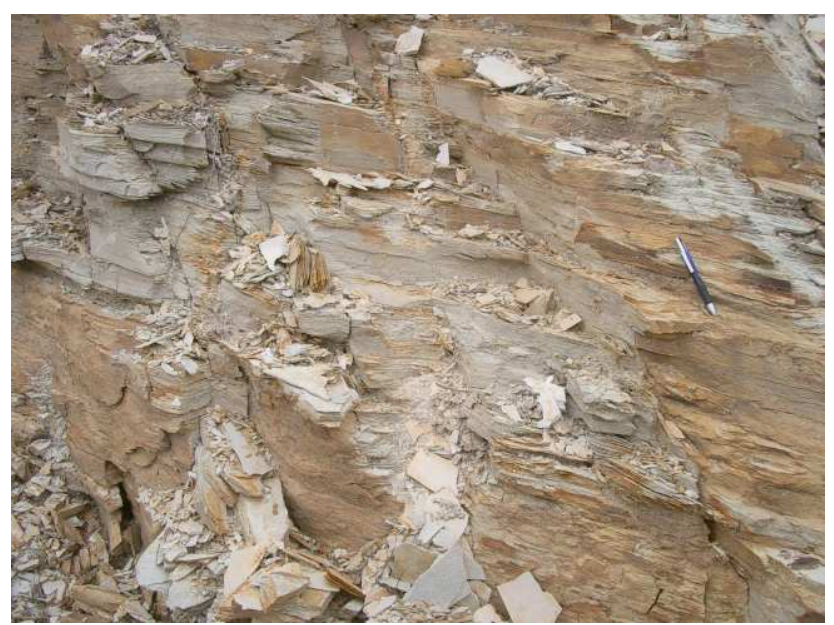

Fig. 2 - Quartzite on Garraia 1 quarry.
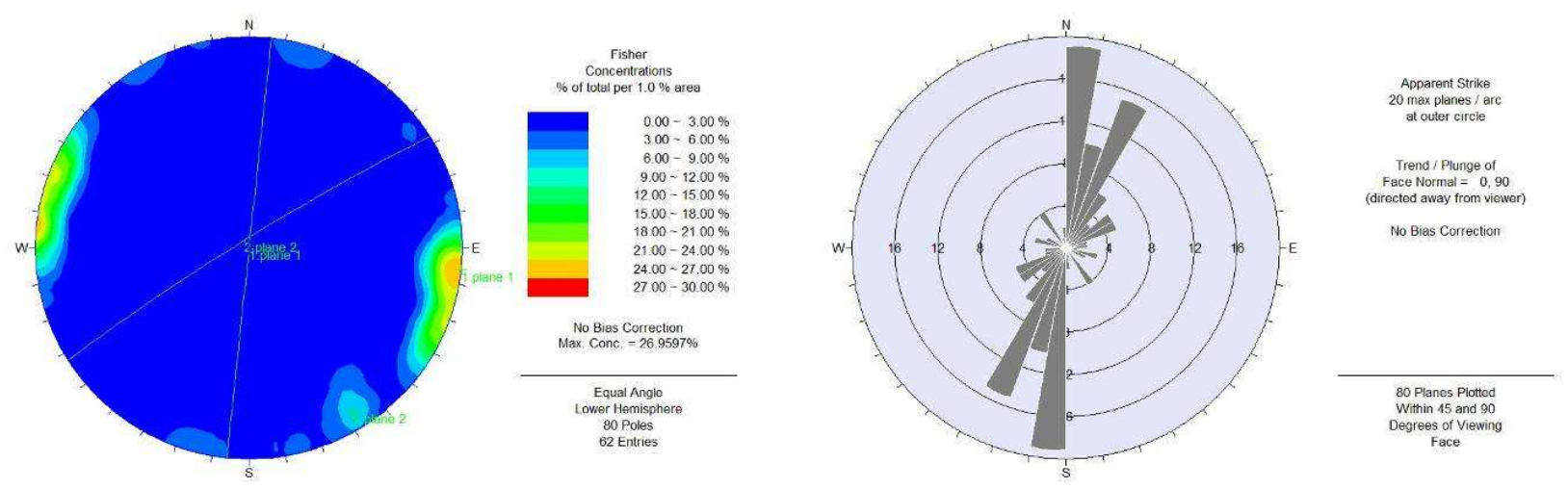

Fig. 3 - Joints diagram from Garraia 1. 
Garraia 2 is a smaller exploitation than Garraia 1. This facies is a less laminated quartzite with whitish colour but exhibiting sometimes a brownish patina. The stratification is parallel to the slate cleavage $\left(\mathrm{N} 75^{\circ} \mathrm{E}, 18^{\circ} \mathrm{N}\right.$ e $\left.\mathrm{N} 55^{\circ} \mathrm{E}, 15^{\circ} \mathrm{N}\right)$. There are some quartz veinlets $\mathrm{N} 120^{\circ} \mathrm{E}, 90^{\circ}$ (Fig.4). The joint systems are represented in Fig. 5.

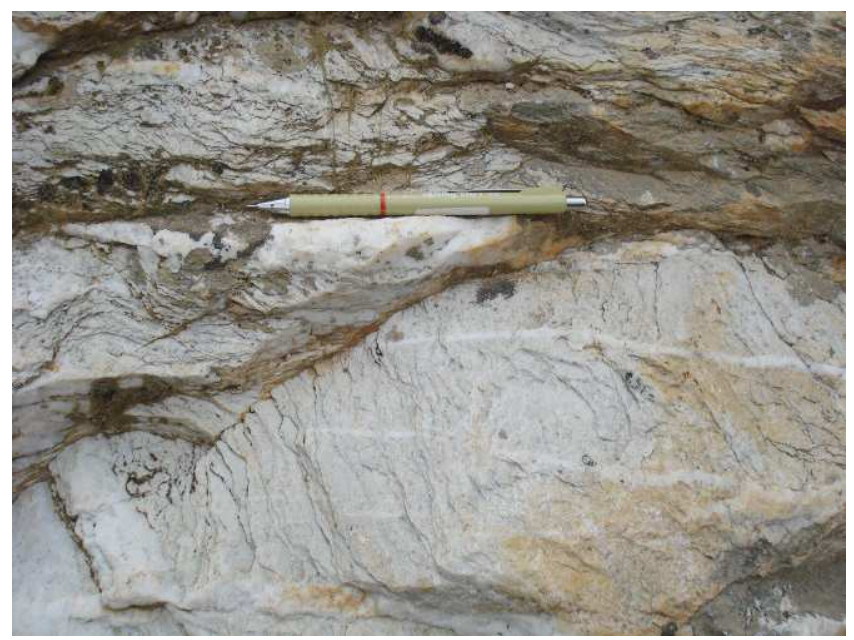

Fig. 4 - Aspect of quartzite with quartz veinlets from Garraia 2.
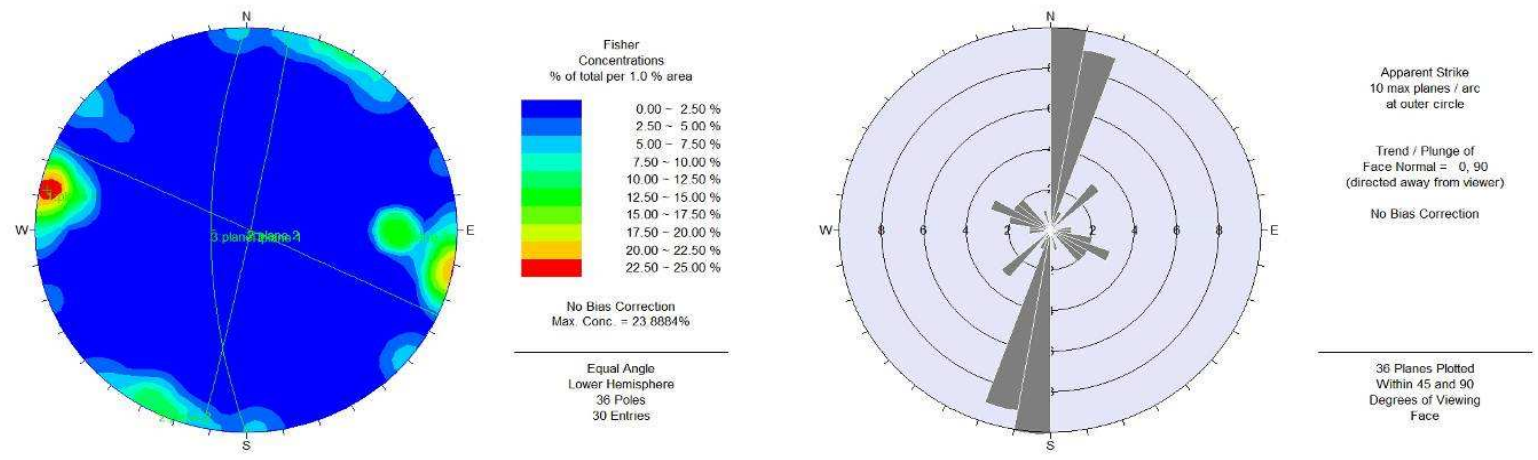

Fig. 5 - Joints diagram from Garraia 2.

Zebras 1 quarry is $25 \mathrm{~m}$ long and $4 \mathrm{~m}$ high on slate quartzite. The rock presents a brownish patina and is well laminated, sometimes exhibiting quartz nodules. The stratification is parallel to the slate cleavage $\left(\mathrm{N} 60^{\circ} \mathrm{E}, 05^{\circ} \mathrm{N}\right)$. The different joint systems are represented in Fig. 6 .
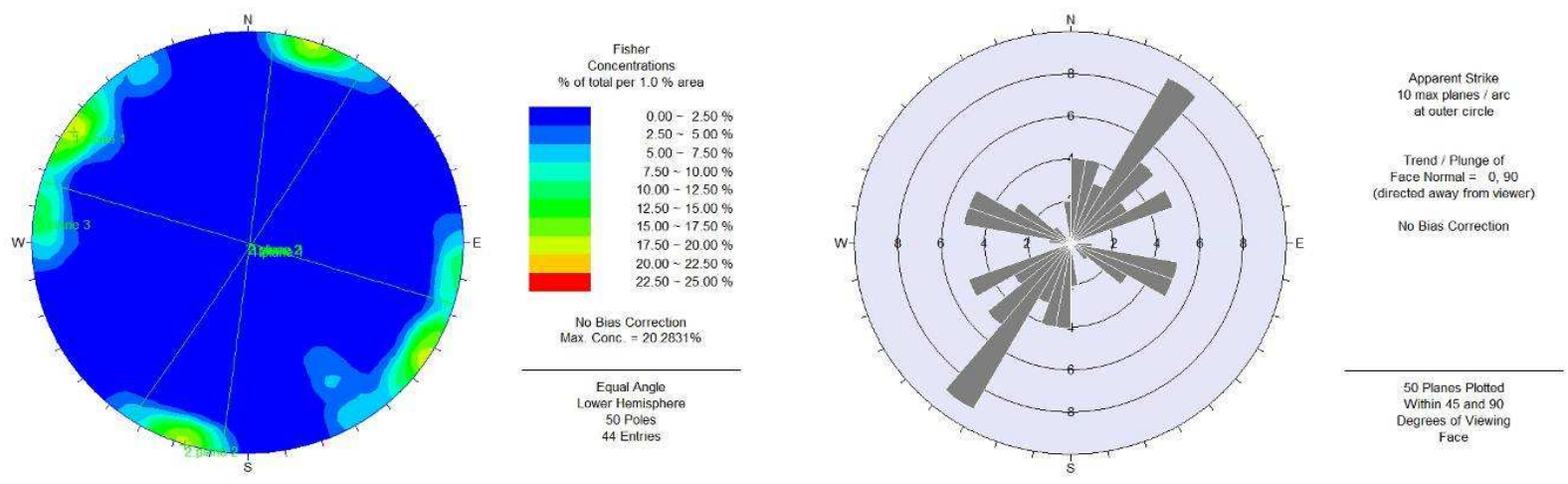

Fig. 6 - Joints diagram from Zebras 1. 
Zebras 2 is a new exploitation, with $2 \mathrm{~m}$ of height on slate quartzite. The slate cleavage $\mathrm{N} 30^{\circ} \mathrm{E}$, $12^{\circ} \mathrm{E}$ is parallel to the stratification. It is well visible a horizontal crenulation $\mathrm{N} 100^{\circ} \mathrm{E}$. There are spaced quartz veinlets $\mathrm{N} 140^{\circ}, 90^{\circ}$. The main joint systems are sub-vertical $\mathrm{N} 10^{\circ} \mathrm{E}$ to $\mathrm{N} 30^{\circ} \mathrm{E} ; \mathrm{N} 60^{\circ} \mathrm{E}$ and $\mathrm{N} 100^{\circ} \mathrm{E}$.

\section{Petrography}

The samples referred as Ga1 and Ga2 are characterized by a light grey colour. They are finely laminated and have an evident slate cleavage. Although the grain size is very small, sometimes small quartz clasts (Ga1) and some oxides (Ga1) are visible. Quartz is the most abundant mineral in these rocks, also having in its composition fine white mica (less important in Ga2), corresponding to a matrix, opaque minerals, zircon and oxides. The texture is granoblastic to lepidoblastic (Fig. 7).

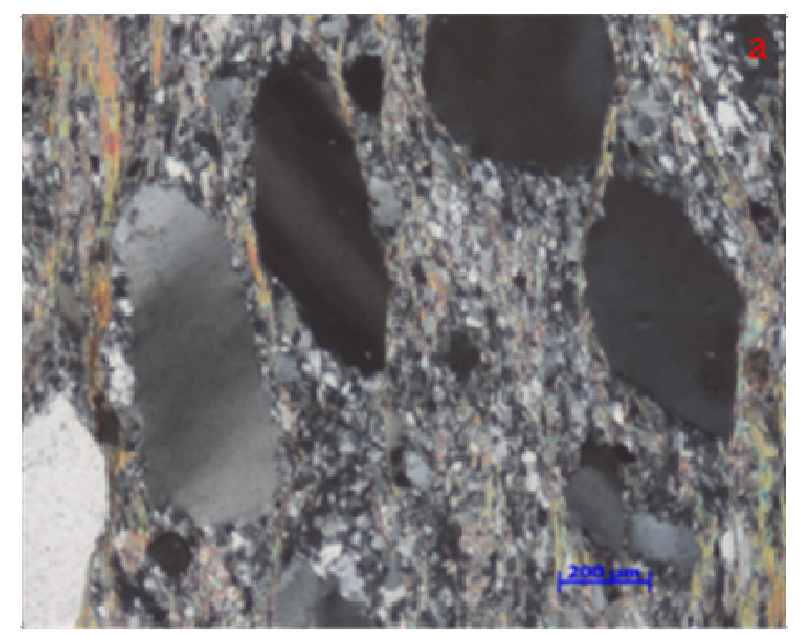

a)

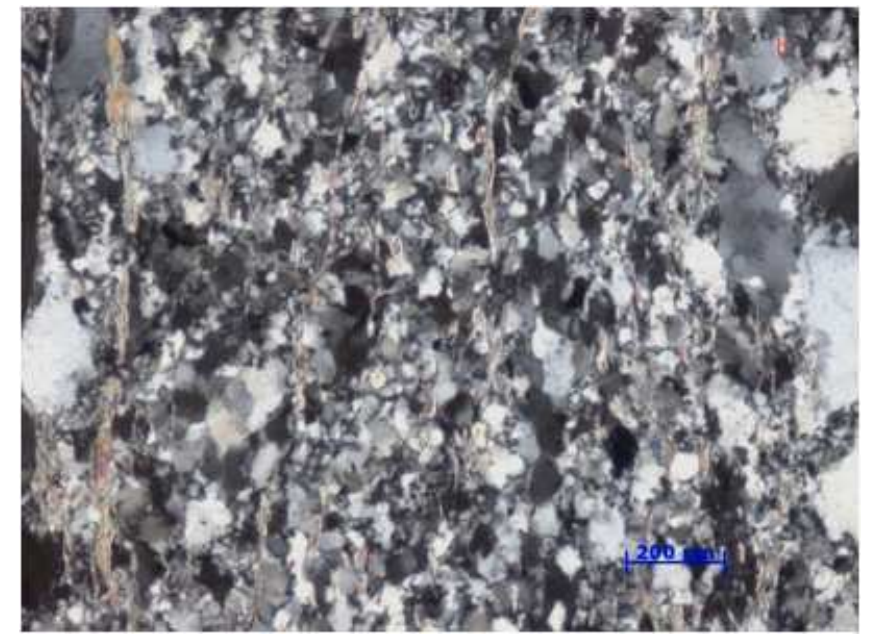

b)

Fig. 7 - a) Lepidoblastic texture with quartz clasts and mica and recrystallized quartz in Ga1; b) lepidoblastic texture in Ga2.

$\mathrm{Zb1}$ is grey colour rock but usually exhibiting a brownish colour (oxidation) (Fig. 8a). This rock has a lepidoblastic texture and foliation marked by alignment of white mica and stretched quartz crystals (Fig. 9a). On its composition, this rock also has opaque minerals, oxides and zircon. Zb2 is a light grey rock (Fig. 8b). In these samples the grain size is very small and the minerals can't be macroscopically identified with the exception of quartz. These rocks have a lepidoblastic texture marked by deformed quartz and white mica (Fig. 9b). Zircon is a usual accessory mineral presenting a round shape.

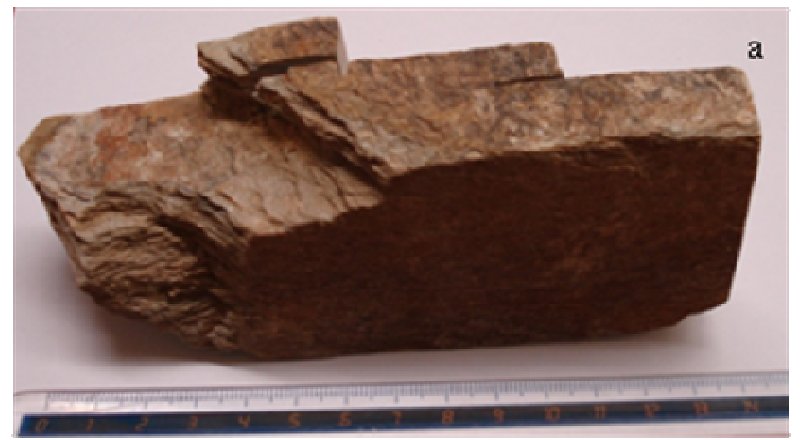

a)

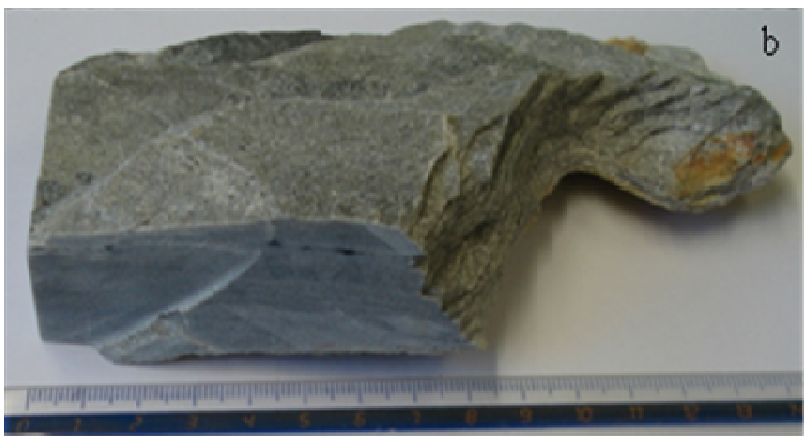

b)

Fig. 8 - a) Zb1 hand sample aspect with brownish colour; b) Zb2 hand sample aspect. 


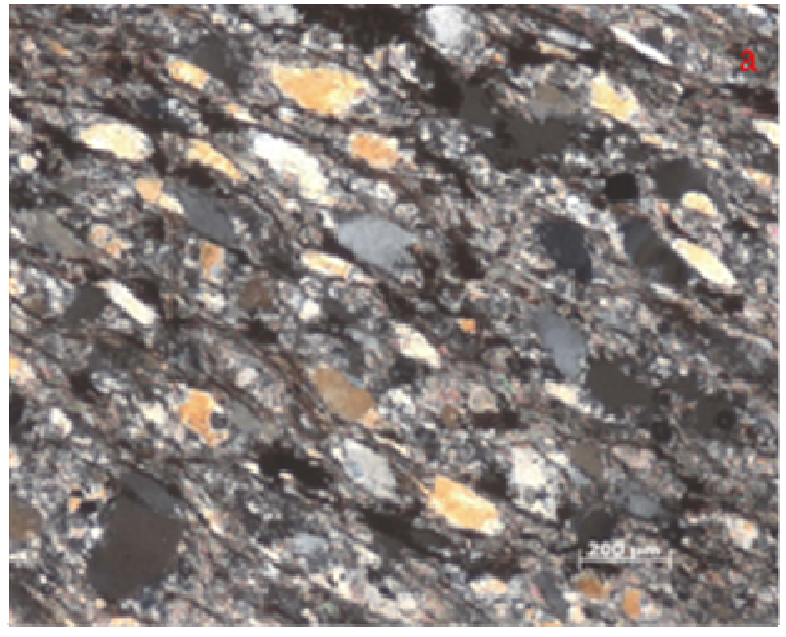

a)

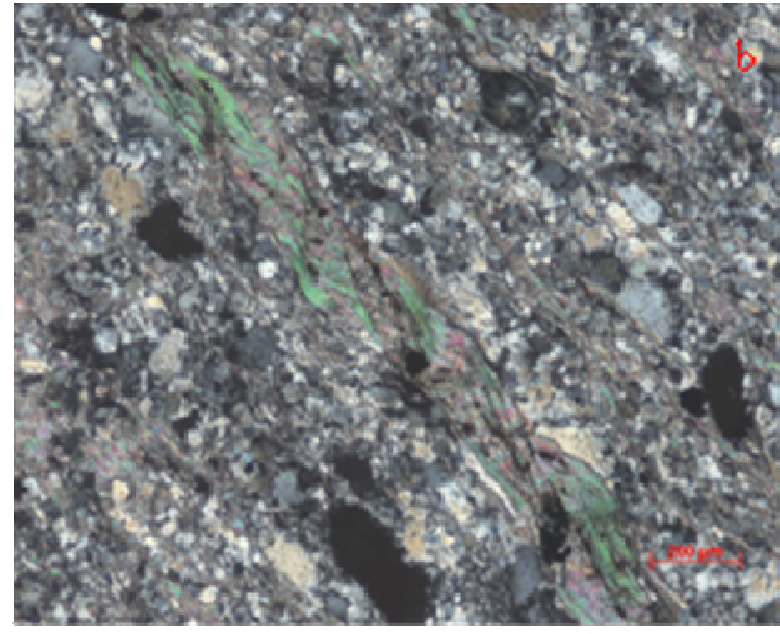

b)

Fig. 9 - a) Lepidoblastic texture, quartz stretched parallel to the foliation in $\mathrm{Zb1}$; b) lepidoblastic texture with crenulation in $\mathrm{Zb} 2$.

The observation of heavy diamagnetic mineral concentrates reveals zircon mixed grains (quartz with opaque minerals). Zircon is present in all studied samples, however, in Ga1 has the peculiarity of being pink, while in the other samples is hyaline or translucent yellow. The paramagnetic fractions showed that the most abundant mineral is an opaque exibithing, in all samples, a rounded shape. The study of this mineral by SEM revealed that it was a titanomagnetite, sometimes with addition of $\mathrm{Cr}$ and $\mathrm{Ni}$. Another paramagnetic mineral also present in all samples is hematite in the form of subhedral crystals. The magnetite is also present in all samples.

\section{Geochemistry}

Table 1 presents the results of chemical analyses for the determination of oxides (in weight percentage) in the rocks Garraia (Ga 1 and $\mathrm{Ga} 2)$ and Zebras ( $\mathrm{Zb} 1$ and $\mathrm{Zb} 2)$ and, for comparative study, two samples from Cubo Unit $(\mathrm{Cb})$ also described as quartzite (MA 132) and quartz phyllite (MA 133) belonging to "Upper Quartzite Formation" at NW of studied quarries at Vila Pouca de Aguiar area [4]. Comparatively, Ga1, Ga2 and $\mathrm{Zb} 2$ rocks are richer in $\mathrm{SiO}_{2}$ with more than $90 \%$ $\left(91.2 \%, 96.0 \%\right.$, and $90.3 \%$, respectively) while $\mathrm{Zb1}$ has $79.13 \%$. Zb1 is the richer in $\mathrm{Al}_{2} \mathrm{O}_{3}$ $(11.44 \%)$ and $\mathrm{Ga} 2$ the poorest $(2.3 \%)$. For the remaining oxides, we must refer the low values of $\mathrm{Na}_{2} \mathrm{O}, \mathrm{CaO}, \mathrm{P}_{2} \mathrm{O}_{5}$ and $\mathrm{MnO}(<0.1 \%)$. The values of $\mathrm{K}_{2} \mathrm{O}$ range between 0.77 and $3.38 \%$, the last one occurring at $\mathrm{Zb1}$ which is also the richest in $\mathrm{Al}_{2} \mathrm{O}_{3}$. The comparison with results from "Cubo Unit" ( $\mathrm{Cb}$ ) suggests that $\mathrm{Ga} 1, \mathrm{Ga} 2$ and $\mathrm{Zb} 2$ corresponds to (meta) quartzites such as MA 132, and $\mathrm{Zb} 1$ corresponds to quartz phyllite as MA 133, with the corresponding greater abundance of white mica.

Fig. 10 presents the $\mathrm{SiO}_{2}$ versus $\mathrm{Al}_{2} \mathrm{O}_{3}$ variation diagram. The analyses reveal that all samples are mineralogically mature $\left(\mathrm{SiO}_{2}>79 \mathrm{wt} \%\right)$. However, they also reveal a different evolution for Garraia and Zebras in terms of textural maturity and mineralogical differentiation. Ga2 sample is the most mature and the most evolved; and $\mathrm{Zb} 1$ sample is the less mature and the less evolved. Ga1 e $\mathrm{Zb} 2$ remain between $\mathrm{Ga} 2$ e $\mathrm{Zb} 1$, but closer on mineralogical differentiation and textural maturity from Ga2. Fig. 11 shows the enrichment in $\mathrm{Al}_{2} \mathrm{O}_{3}$ and $\mathrm{TiO}_{2}$ from $\mathrm{Ga} 2$ to $\mathrm{Zb} 1$ related to the amount of matrix, which is poor in $\mathrm{Ga} 2$ and more abundant in $\mathrm{Zb1}$; so it is probable that the ilmenite is associated with micaceous matrix. 
Table 1. Results of chemical analyses for the determination of oxides in the rocks.

\begin{tabular}{|c|c|c|c|c|c|c|c|}
\hline & & $\begin{array}{r}\mathrm{Ga} 1 \\
(1)\end{array}$ & $\begin{array}{r}\mathrm{Ga} 2 \\
(2)\end{array}$ & $\begin{array}{r}\mathrm{Zb1} \\
\text { (3) }\end{array}$ & $\begin{array}{r}\mathrm{Zb} 2 \\
\text { (4) }\end{array}$ & $\begin{array}{r}132 \\
\text { MA) }\end{array}$ & $\begin{array}{r}\text { MA } 133 \\
(6)\end{array}$ \\
\hline $\mathrm{SiO}_{2}$ & [wt\%] & 91.2 & 96.02 & 79.13 & 90.3 & 92.50 & 78.99 \\
\hline $\mathrm{Al}_{2} \mathrm{O}_{3}$ & {$[\mathrm{wt} \%]$} & 4.62 & 2.3 & 11.44 & 4.86 & 4.69 & 10.48 \\
\hline $\mathrm{Fe}_{2} \mathrm{O}_{3} *$ & {$[\mathrm{wt} \%]$} & 1 & 0.63 & 2.82 & 0.96 & 0.32 & 3.08 \\
\hline $\mathrm{MnO}$ & [wt\%] & 0.002 & 0.002 & 0.007 & 0.003 & 0.00 & 0.03 \\
\hline $\mathrm{MgO}$ & {$[\mathrm{wt} \%]$} & 0.14 & 0.07 & 0.36 & 0.13 & 0.00 & 0.65 \\
\hline $\mathrm{CaO}$ & [wt $\%]$ & 0.03 & 0.01 & 0.02 & 0.01 & 0.00 & 0.08 \\
\hline $\mathrm{Na}_{2} \mathrm{O}$ & [wt\%] & 0.03 & 0.02 & 0.09 & 0.04 & 0.02 & 0.85 \\
\hline $\mathrm{K}_{2} \mathrm{O}$ & {$[\mathrm{wt} \%]$} & 1.6 & 0.77 & 3.38 & 1.62 & 1.16 & 2.83 \\
\hline $\mathrm{TiO}_{2}$ & {$[\mathrm{wt} \%]$} & 0.207 & 0.1 & 0.506 & 0.193 & 0.16 & 0.48 \\
\hline $\mathrm{P}_{2} \mathrm{O}_{5}$ & {$[\mathrm{wt} \%]$} & $<0.01$ & $<0.01$ & 0.05 & 0.02 & 0.00 & 0.11 \\
\hline L.O.I.** & {$[\mathrm{wt} \%]$} & 0.81 & 0.34 & 2.26 & 0.92 & 1.02 & 2.17 \\
\hline Total & [wt\%] & 99.65 & 100.3 & 100.1 & 99.05 & 99.87 & 99.75 \\
\hline
\end{tabular}

(1) Quartzite; (2) Quartzite; (3) Quartz phyllite; (4) Quartzite; (5) Quartzite [4]; (6) Quartz phyllite [4].

* total $\mathrm{Fe}$ as $\mathrm{Fe}_{2} \mathrm{O}_{3}$; ** Loss On Ignition.

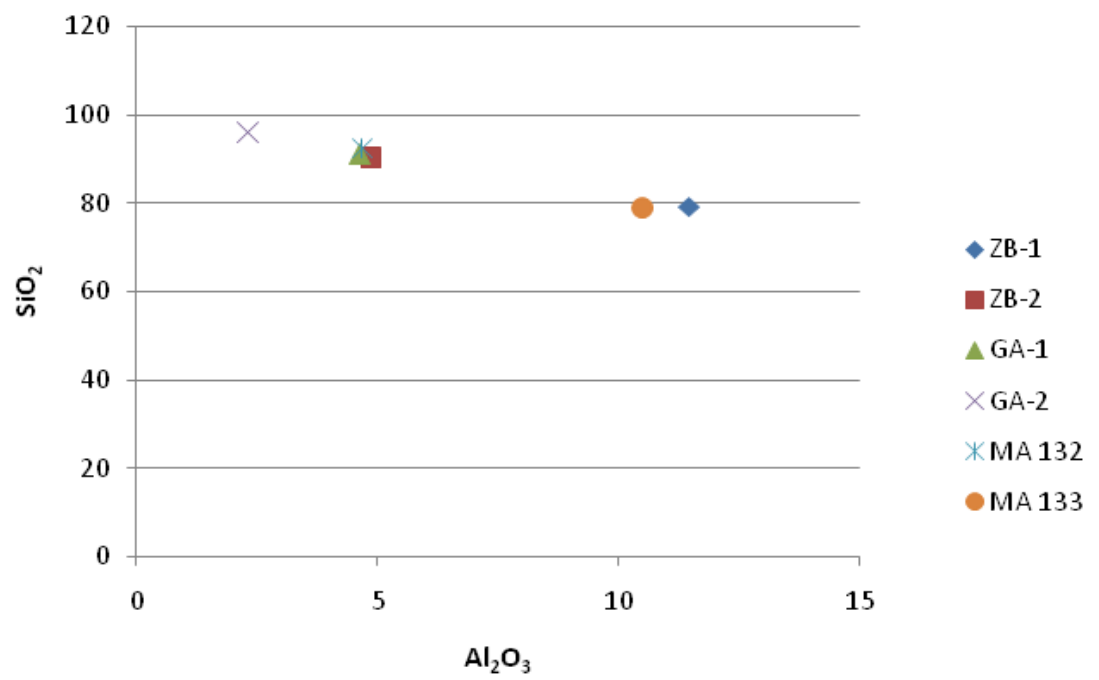

Fig. $10-\mathrm{SiO}_{2}-\mathrm{Al}_{2} \mathrm{O}_{3}$ variation

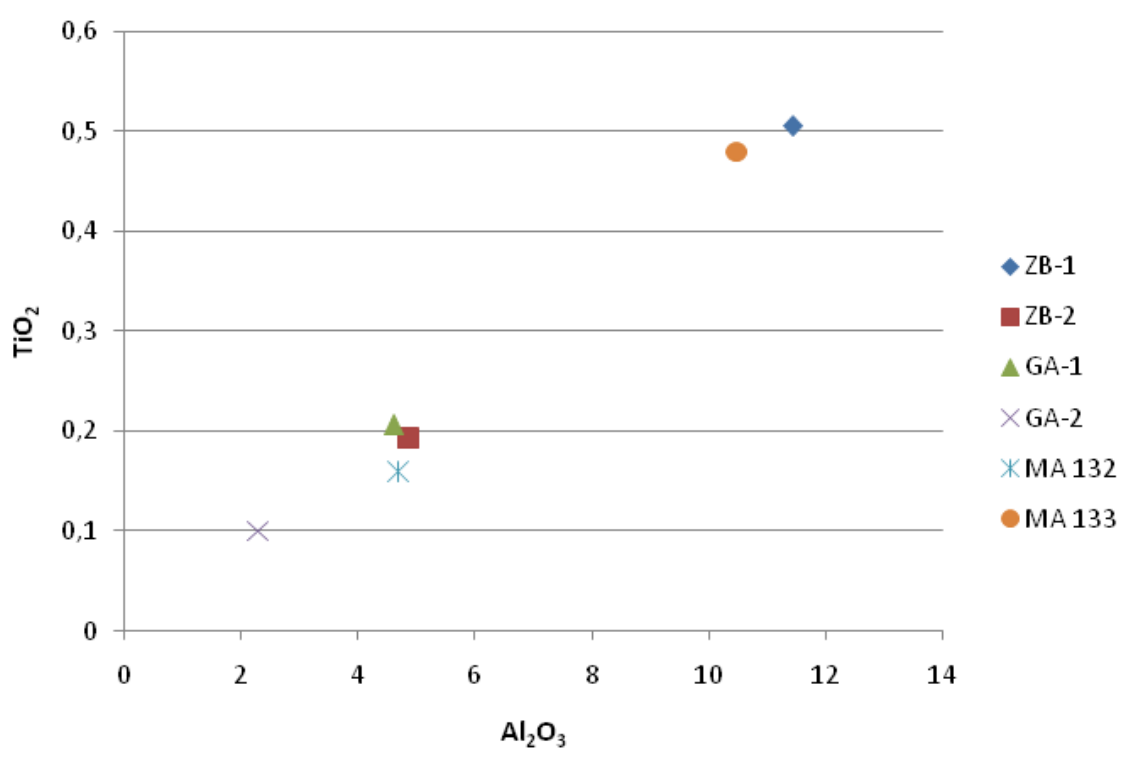

Fig. $11-\mathrm{TiO}_{2}-\mathrm{Al}_{2} \mathrm{O}_{3}$ variation diagram. 


\section{Physical and Mechanical Characterization}

The rocks under study were subjected to tests for determination of their physical and mechanical characteristics and definition of their use [5]. The results obtained for each rock are summarized in Table 2. Fig. 12 shows the aspect of Zebras' specimens after compressive strength test and the Zb1 and $\mathrm{Zb} 2$ specimens aspect after flexural strength under concentrated load test. At the end of the 20 cycles of thermal shock, the samples don't show substantial modifications on their aspect.

Table 2. Results of physical and mechanical tests.

\begin{tabular}{lccc}
\hline & $\mathrm{Ga} 1$ & $\mathrm{Zb} 1$ & $\mathrm{Zb2}$ \\
\hline Water absorption at atmospheric pressure, [\%] & 0.7 & 0.3 & 0.3 \\
Apparent density, [kg/m $\left.{ }^{3}\right]$ & 2630 & 2630 & 2650 \\
Open porosity, [\%] & 1.6 & 0.8 & 0.8 \\
Compressive strength, [MPa] & 150 & 89 & 87 \\
Flexural strength under concentrated load, [MPa] & 35.6 & 29.6 & 37.7 \\
Abrasion resistance - Wide wheel abrasion test, [mm] & 19 & 18.5 & 16.5 \\
Resistance to ageing by thermal shock, [loss of mass \%] & 0.07 & 0.01 & 0.03 \\
\hline
\end{tabular}
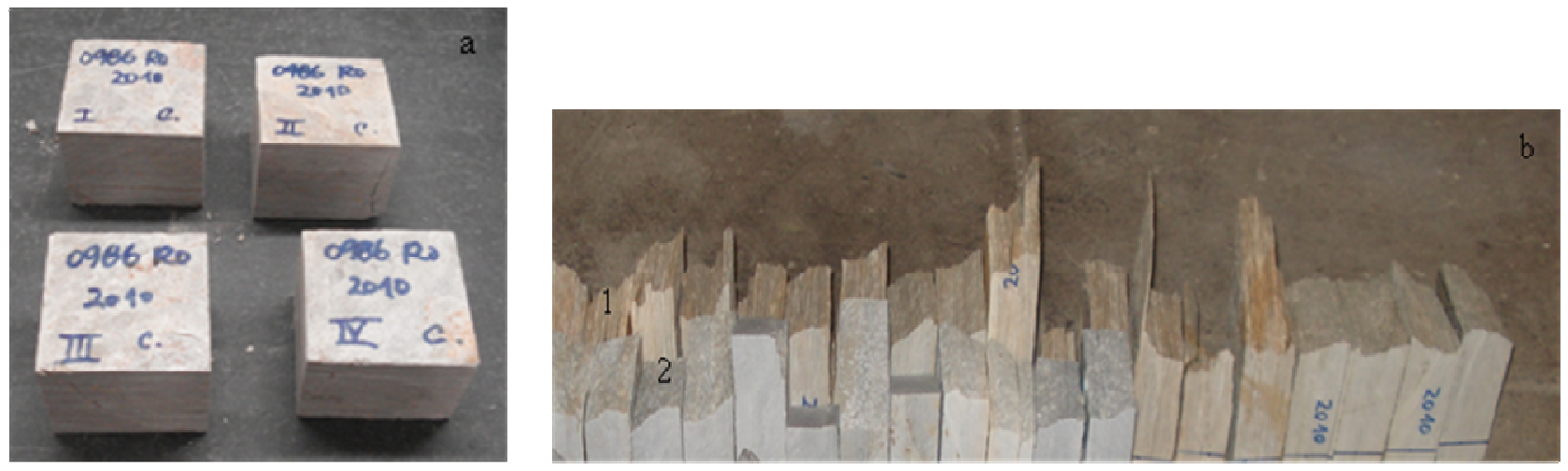

Fig. 12 - a) Zb1 specimens after compressive strength test; b) Zb1 (1) and Zb2 (2) specimens after flexural strength under concentrated load test.

\section{Concluding Remarks}

The analysed samples are laminated rocks, with fine granularity and different degrees of oxidation. In $\mathrm{Ga} 2$ and $\mathrm{Zb} 2$ samples the grain size is very small and the minerals cannot be macroscopically identified, but in $\mathrm{Gal}$ and $\mathrm{Zb1}$ it is possible to identify small quartz clasts.

Using petrographic methods, it is possible to identify a specific orientation of the quartz and white micas, which confers to all the rocks a lepidoblastic texture. In their mineralogical composition, all the samples present opaque minerals, identified by SEM (being titanomagnetite more abundant, and hematite). Ga2 presents less mica and more quartz content, which indicates absence of matrix. $\mathrm{Zb} 1$ is the richest in mica. This fact confirms the results obtained from the chemical analysis; $\mathrm{Ga} 2$ is the sample with the highest content of $\mathrm{SiO}_{2}(96.02 \%)$ and the lowest content of $\mathrm{Al}_{2} \mathrm{O}_{3}(2.3 \%)$. On the contrary, $\mathrm{Zbl}$ presents the lowest content of $\mathrm{SiO}_{2}(79.13 \%)$ and the highest content of $\mathrm{Al}_{2} \mathrm{O}_{3}(11.44 \%)$.

The $\mathrm{SiO}_{2}$ and $\mathrm{Al}_{2} \mathrm{O}_{3}$ values and the petrographic studies revealed a different evolution for Garraia and Zebras in terms of textural maturity and mineralogical differentiation. Ga2 sample is the most mature and the most evolved and $\mathrm{Zbl}$ sample is the less mature and the less evolved. The studies 
allowed the distinction between quartzites and quartz phyllites: Ga1, Ga2 and $\mathrm{Zb} 2$ are quartzites and Zb1 a quartz phyllite.

The results obtained from the physical and mechanical laboratorial tests indicate the applicability of the rock types (Table 3 ).

Table 3. Rocks applicability.

\begin{tabular}{lccc}
\hline & Ga1 & Zb1 & Zb2 \\
\hline Rustic masonry & + & + & + \\
Resistant masonry / columns & + & + & + \\
Pavements of high traffic & conditioned use outdoors & + & \\
Pavements of very high traffic & & & + \\
Cladding & mainly indoors & + & + \\
\hline
\end{tabular}

\section{Acknowledgements}

This work was performed under the project PTDC/CTE-GIN/70704/2006, "SCHISTRESOURCE" funded by FCT - Portuguese Foundation for Science and Technology. Sílvia Aires benefit from a FCT grant.

\section{References}

[1] F. Noronha, C. Carvalho, S. Aires, A. Casal Moura, J. Farinha Ramos: Characterization of "Xisto" as a Way to Promote its Use as Natural Stone, Proceedings of Global Stone Congress 2012, (in this volume of Key Engineering Materials).

[2] E. Pereira (Coord): Carta Geológica de Portugal à escala 1:200 000, Folha 2, Instituto Geológico e Mineiro, Portugal (2000).

[3] E. Pereira (Coord): Notícia Explicativa da Folha 2 da Carta Geológica de Portugal à escala 1/200 000, INETI, Lisboa, 119 pp. (2006).

[4] M.A.M. Ribeiro: PhD Thesis, Faculdade de Ciências da Universidade do Porto, 231 pp. (1998).

[5] C. Carvalho, S. Aires, F. Noronha, A. Casal Moura, J. Farinha Ramos: "Schist" from Trás-osMontes and Alto Douro (NE of Portugal): Potential Use as Natural Stone, Proceedings of Global Stone Congress 2012, (in this volume of Key Engineering Materials). 